\title{
Does The Market See Through Seasonal Quarterly Earnings Patterns?
}

\author{
John M. Carlson, Albion College, USA
}

\begin{abstract}
Evidence such as Das, Shroff, and Zhang (2009) suggests that firms routinely reverse their earnings pattern during their fourth quarter compared to that of last year, possibly leading to earnings management. Motivated by these findings, this study seeks to document whether the market sees through seasonal quarterly earnings patterns and reacts consistent with an earnings management hypothesis. Using an amended Easton and Harris (1991) model, I study whether the earnings variables are more informative based upon the seasonal differencing patterns by incorporating dummy variables, along with their respective interaction terms, to signify the first time the pattern occurs. My results show the market sees the seasonal quarterlyearnings pattern; the earning levels and changes in earnings variables are more informative but the (managed) earnings tend to be transitory, not permanent in nature. All othertests performed support these general conclusions.
\end{abstract}

Keywords: Quarterly Earnings Patterns; Earnings Management; Information Content

\section{INTRODUCTION}

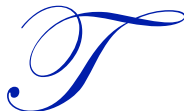

his study asks a very specific question: Does the market see through seasonal quarterly earnings patterns? The idea is motivated by Das, Shroff, and Zhang (2009) who investigated seasonal quarterly earnings patterns and found firms that had fourth quarter reversal patterns, as compared to matched control firms, had traits or characteristics that were similar to firms that were earmarked for earnings management using earlier testing procedures such as accruals testing (size, direction, and discretionary), special items, and real earnings management.

Pervasive existence of fourth quarter reversal phenomenon is not necessarily a priori evidence that the market does not see through the phenomenon. Even if the market can see through the seasonal differencing pattern, management may use this as a tool to convey additional information. Income smoothing has been argued as a way to signal "good news". Income smoothing dampens fluctuations around a perceived normal earnings number (Beidleman 1973) and seems to be rewarded by the stock market because investors hate surprises (Trueman and Titman (1988); Graham, Harvey, and Rajgopal (2005)). On the other hand, firms may want to fool the market in order to maintain or increase the existing stock price, earn personal incentives for management, or minimize third-party interference lenders, government, or other stakeholders according to Schipper (1989) and Healy and Wahlen (1999). Therefore, the market's possible inability to notice and react to the reversal pattern would be consistent with the conventional wisdom of the earnings management literature.

To test whether the market sees through seasonal quarterly earnings patterns, I modify the Easton and Harris (1991) model $^{1}$ by incorporating dummy variables to identify the first time a firm incurred one of two possible seasonal quarterly earnings patterns. Das et al. (2009) hypothesized firms are more likely to adjust their earnings during their fourth quarter when the most timely and relevant information is available and developed two types of seasonal quarterly earnings patterns based upon the idea of "fourth quarter reversals". The first type (Np) is defined if at least two of the three interim seasonal quarter differences are negative and the fourth quarter seasonal difference is positive and the second type (Pn) is defined if at least two of the three interim seasonal quarters are positive and the fourth quarter difference is negative.

${ }^{1}$ I replicated Easton and Harris (1991) for my sample and found similar results.

Copyright by author(s); CC-BY 
If the model is well-specified, the Easton and Harris (1991) earnings levels and changes variables will represent the "pre-event" results and as the first time seasonal pattern emerges, the dummy variable(s) will be significant and their respective interaction terms for the first time time event will represent the "post-event" results. A significant dummy variable coefficient suggests the post-event results are more informative and that the market sees through the first time seasonal quarterly earnings patterns. Significant earnings response coefficients on the interaction earnings levels and/or changes in earnings levels variables suggest the market found the seasonal quarterly earnings patterns more informative.

This paper makes an incremental contribution to the information content literature by empirically testing whether either or both the first time seasonal quarterly earnings patterns are seen by the market and if so, to the extent the market rewards or punishes firms with the seasonal patterns.

The rest of the paper is organized as follows: section 2 presents the literature review and hypothe sis development, section 3 describes the sample selection and research design, section 4 discusses the results, and sections 5 provides the conclusion and suggests future research.

\section{LITERATURE REVIEW AND HYPOTHES IS DEVELOPMENT}

A firm periodically presents its operating results with one number: earnings. Earnings serve as a signal that helps the direct resource allocations in the capital markets (Kieso, Weygandt, and Warfield, 2012) and earnings is considered the most important metric because of the comple xity of business in general, media focus, and for the ease of financial analysts (Graham et al. 2005), or to put it simply "investors buy earnings" (Penman 2007).

Earnings is the product of accrual accounting and is basically the combination of net cash flows from operations adjusted by various accruals. Ideally, accruals, driven by existing accounting principles and policies, attempt to capture additional information based upon the time frame of the transaction or economic occurrence ${ }^{2}$, not when cash is collected or paid. Accrual accounting is driven by the double-entry bookkeeping system therefore accruals affect both the firm's earnings and its book value; and by definition the double-entry bookkeeping system cause all accruals to ultimately reverse (Palepu, Healy, Bernard, and Peek (2007).

But there is another side to accruals. Firms have the ability to intervene in the financial reporting process (Schipper 1989) and since management intent is unobservable, they can manage accruals, upward or downward, to report numbers they want to report ${ }^{3}$. Schipper defined earnings management as a "game of disclosure management". Given the professional judgment inherent by design in accounting principles, firms have flexibility within GAAP to make estimates and establishing policies based upon the economics of the situation or based upon the need to time or shift earnings. This flexibility, when abused, has been described as earnings management. But this disclosure game can be perceived in two ways: to deceive the financial statement readers or to main tain the investors' piece of mind by maintaining less volatile fluctuations in earnings.

Existing empirical literature argue firms manage earnings to deceive the financial statement reader for a variety of reasons: Badertscher (2011) found firms tend to transition from accruals management to real transaction management in order to maintain an overvalued stock price; Barth, Elliott and Finn (1999) found that the market rewards earnings growth while Skinner and Sloan (2002) documented the market will punish severely a small earnings disappointment. Additional research found firms may manage earnings towards different benchmarks. Burgstahler and Dichev (1997) established firms will manage earnings to avoid annual losses and earnings decreases. Degeorge, Patel, and Zeckhauser (1999) established and prioritized three benchmarks that firms will manage earnings in the following order: annual earnings greater than zero, this year's profit greater than last year's, and meeting or beating analysts' expectations.

\footnotetext{
${ }^{2}$ Earnings is not a perfect summary of events. Extant research has found a lag between an event occurrence and the subsequent reporting (East on, Harris, and Ohlson 1992, Warfield and Wild 1992, and Basu 1997).

${ }^{3}$ Assuming the absence of fraud, there are limits to accrual adjust ments if the firm stays within GAAP. Levels of prior year net operating as sets (Barton and Simko 2002), or the level of an existing "bloated balance sheet"(Hirshleifer, Hou, Teoh, and Zhang 2004) limit accruals earnings management, and Badertscher (2011) found firms move from accrual earnings management to real earnings management the longer the firm is overvalued by the market.
}

Copyright by author(s); $\underline{\text { CC-B Y }}$ 
On the other hand, managing earnings can be perceived in a positive light. Ronen and Sadan (1981) argued income smoothing is a form of signaling. Smoothing allows a firm to build "a stable earnings stream" and signals to investors, management's commit to dividend declaration and future growth. Income smoothing is defined as "the intentional dampening of fluctuations about some level of earnings that is currently considered normal for a firm" (Beidleman 1973). Smoothed earnings is preferred by many CFOs as they believe it is perceived by the market as less risky, makes it easier for the market to predict future earnings, and contributed to a lower overall cost of capital Graham, Harvey and Rajgopal (2005).

I use the Easton and Harris (1991) regression model ${ }^{4}$ amended by the seasonal quarterly differencing methodology by Das et al. (2009) for my testing. Easton and Harris (1991) contributed toward the information content of earnings literature where the degree of "new" information is the relationship between stock returns and unexpected earnings or how quickly earnings alter investors' beliefs and capture the information set that is reflected in the market. In the standard returns/earnings model, the degree of "new" information is inferred from the significance of the slope (earnings response coefficient) on the accounting variable(s) and the explanatory power (R2) of the model over time (Lev 1989; Easton, Harris and Ohlson 1992).

Given that "true earnings" is unobservable, the change in annual earnings divided by the beginning of the year stock price was considered the "theoretically correct" concept of the earnings variable. An underlying assumption being current earnings approximated expected earnings; therefore, the change in annual earnings can be used as a proxy for unexpected earnings. Earlier research had found price changes and earnings changes were positively, but not perfectly correlated (Ball and Brown 1968). Only a portion of the earnings change is a surprise to the market. The anticipated portion is irrelevant in explaining returns. Dividing the earnings variable(s) by the beginning of the year price makes the earnings consistent with returns (Ohlson and Shroff 1992) based upon the efficient market assumption that the beginning of the year price has incorporated all available information to date (Fama 1991). Easton and Harris (1991)'s contribution was to empirically show that including earnings levels along with changes in earnings levels were relevant and in fact the two variables complement one another in evaluating the returns/earnings associations. Ali and Zarowin (1992) found the annual earnings levels variable acts as an additional proxy for unexpected earnings when the previous year's earnings were not purely permanent. The mo re transitory the previous year's earnings, the greater the expected incremental explanatory power of the earnings levels coefficient. Easton and Harris (1991) and Ali and Zarowin (1992) found earnings changes capture the permanent component of earnings while earnings levels have a transitory component, a component that effects the current year's earnings only.

Das et al. (2009) identified two fourth quarter reversal patterns: Np firms whose seasonal differencing of at least two of three interim quarters were lower, but their fourth quarter differencing was higher, and Pn firms whose seasonal differencing of at least two of three interim quarters were higher, but their fourth quarter differencing was lower. Das found that the frequency of firms using the quarterly earnings pattern was higher than by chance and concluded that firms may be managing earnings upward ( $\mathrm{Np}$ ) or downward $(\mathrm{Pn})$ in the fourth quarter. Das suggested the market apparently sees through these patterns, especially in terms of discretionary accruals ${ }^{5}$, and discounts the earnings of $\mathrm{Np}$ firms while rewarding or placing a greater weight on the earnings of Pn firms. I also include two interaction variables for each fourth quarter reversal pattern: one for earnings level and one for changes in earnings level to measure the incremental explanatory power of the patterns.

Given the conflicting arguments that managed earnings are to deceive versus to inform the market, I align my sample based upon the first time ("first event") a firm qualifies as an Np or Pn based upon the Das et al. (2009) design. To test for the informational content of the respective first event pattern, I propose the following hypotheses:

\footnotetext{
${ }^{4}$ Earnings "levels" is annual basic EPS before discontinued operations and extraordinary items and "changes" is the current year earnings lev el less the prior year earnings level. Both variables are divided by the beginning of the year stock price with the assumption the begin $\mathrm{n}$ ing of the year stock price reflects the market's future expected earnings.

${ }_{5}^{5}$ Defond and Park (2001) ex pected higher ERCs when accruals suppress earnings surprises and lower ERCs when accruals were used to magnify earnings surprises.
}

Copyright by author(s); CC-B Y 
H1: The market cannot identify first event $\mathrm{Np}$ firms for the traditional year-end.

H2: The market cannot identify first event Pn firms for the traditional year-end.

To investigate this question further, I ask the question: What if a firm had three interim quarter seasonal differencing going one direction and reversing itself in the fourth quarter for the same calendar year? In other words, for the three interim quarters the seasonal differencing was negative and fourth quarter positive and vice versa. To test for the informational content of this more restrictive first event approach, I propose the following hypotheses:

H3: The market cannot identify restricted first event $\mathrm{Np}$ firms for the traditional year-end.

H4: The market cannot identify restricted first event Pn firms for the traditional year-end.

If the dummy variables and/or their respective interaction terms are not significant, then the market cannot see the pattern. I predict the market will see the pattern as triggered by the respective dummy variable and react negatively; the market returns will be lower (higher) for the $\mathrm{Np}(\mathrm{Pn})$ designation. I predict the coefficients on the $\mathrm{Np}(\mathrm{Pn})$ earnings levels interaction variables to be negative (positive) and significant and the coefficients on the Np (Pn) earnings changes interaction variables to be not significant suggesting the market sees through the rounding up (down) pattern and deems it to be transitory.

\section{SAMPLE SELECTION, RESEARCH DESIGN, AND REGRESSION MODELS}

I selected only US firms with calendar year-ends with common shares traded on the NYSE, AMEX, or NASDAQ for the years 1971- 2006. The monthly security holding returns were acquired from CRSP and the fundamental quarterly basic EPS excluding extraordinary items and the quarter-end stock prices adjusted for all cumulative stock adjustments (stock splits and stock adjustments) were pulled from the CRSP/Compustat merged database. The final sample, summarized in Table 1, totaled 30,904 observations (2,670 firms) from 1971 through 2006. The firm observations by year ranged from a low of 39 in 1971 to a high of 1,990 in 2003 . Overall $12.5 \%$ of the total sample, qualified as fourth quarter reversals $(5.8 \%$ as $\mathrm{Np}$ and $6.7 \%$ as $\mathrm{Pn}$ ) which is approximately half the size of the Das results ${ }^{6}$. Yearly analysis is consistent with the total sample results although it appears that over time the overall seasonal differencing activity increases. Approximately $67 \%(1,791)$ of the firms qualified as a Pn or a $\mathrm{Np}$ at least once during the thirty-five year time span which accounted for $79 \%(24,414)$ of the total observations. The total number of Pns and Nps within the sample is 2,087 and 1,832 respectively.

Table 1. Total Sample

\begin{tabular}{l|l|c|c|c|c}
\hline \multicolumn{1}{c|}{ Sample Mix } & \multicolumn{1}{|c|}{ Definition } & $\begin{array}{c}\text { \# of } \\
\text { Observations }\end{array}$ & \# of Firms & $\begin{array}{c}\text { \% of } \\
\text { Observations }\end{array}$ & \% of Firms \\
\hline No Pattern & No Pn or Np Activity & 6,490 & 879 & $21 \%$ & $33 \%$ \\
\hline Only Pn Pattern & At Least 1 Pn but NO Np event & 6,654 & 558 & $22 \%$ & $21 \%$ \\
\hline Only Np Pattern & At Least 1 Np but NO Pn event & 4,961 & 500 & $16 \%$ & $19 \%$ \\
\hline Both & At least one of each & 12,799 & 733 & $41 \%$ & $27 \%$ \\
\hline Total Sample & & 30,904 & 2,670 & & \\
\hline
\end{tabular}

Table 2 presents the descriptive statistics for market returns (Ret), earnings level (L), and change in earnings level (C) by grouping for the sample. For possible monthly stock return outliers, I removed the highest and lowest $1 \%$ and for possible earnings levels and changes in earnings outliers, I used the Easton and Harris (1991) criteria and removed all observations not within the -1.5 and +1.5 range for each year-end grouping. The difference in the median market returns between the "Only Pn" group (0.14), the "Only Np" group (0.07) versus the total sample (0.11) suggest investigating this is sue further.

\footnotetext{
${ }^{6}$ This could be due to my approach to exclude $4^{\text {th }}$ quarter differences ranging from $-.01<\mathrm{x}<.01$ from my Np and Pn subsets. Copyright by author(s); $\underline{\text { CC-B Y }}$ 
Table 2. Descriptive Statistics by Grouping

\begin{tabular}{|c|c|c|c|c|c|c|c|}
\hline Variable & Definition & Min. & $25 \%$ & Mean & Median & $75 \%$ & Max. \\
\hline \multicolumn{8}{|l|}{ No Pattern } \\
\hline Ret & Market Return t & -0.83 & -0.15 & 0.17 & 0.10 & 0.40 & 3.14 \\
\hline $\mathrm{L}$ & Basic EPS t (level)/Price per share $t-1$ & -1.41 & 0.00 & 0.02 & 0.05 & 0.08 & 1.10 \\
\hline $\mathrm{C}$ & Change in Basic EPS t/ Price per share $t-1$ & -1.39 & -0.01 & 0.01 & 0.01 & 0.03 & 1.43 \\
\hline \multicolumn{8}{|l|}{ Only Pn } \\
\hline Ret & Market Return t & -0.82 & -0.08 & 0.18 & 0.14 & 0.38 & 3.04 \\
\hline $\mathrm{L}$ & Basic EPS t (level)/Price per share $t-1$ & -1.4 & 0.04 & 0.07 & 0.07 & 0.10 & 1.42 \\
\hline $\mathrm{C}$ & Change in Basic EPS t/ Price per share $t-1$ & -1.35 & -0.01 & 0.01 & 0.01 & 0.02 & 1.41 \\
\hline \multicolumn{8}{|l|}{ Only Np } \\
\hline Ret & Market Return t & -0.82 & -0.18 & 0.15 & 0.07 & 0.38 & 3.14 \\
\hline $\mathrm{L}$ & Basic EPS t (level)/Price per share $t-1$ & -1.45 & -0.04 & 0.00 & 0.04 & 0.08 & 1.08 \\
\hline $\mathrm{C}$ & Change in Basic EPS t/ Price per share $t-1$ & -1.32 & -0.03 & 0.01 & 0.01 & 0.04 & 1.49 \\
\hline \multicolumn{8}{|l|}{ Both } \\
\hline Ret & Market Return t & -0.82 & -0.10 & 0.16 & 0.11 & 0.35 & 3.12 \\
\hline $\mathrm{L}$ & Basic EPS t (level)/Price per share $t-1$ & -1.47 & 0.03 & 0.06 & 0.07 & 0.11 & 1.48 \\
\hline $\mathrm{C}$ & Change in Basic EPS t/ Price per share $t-1$ & -1.49 & -0.17 & 0.01 & 0.01 & 0.03 & 1.50 \\
\hline \multicolumn{8}{|c|}{ Total Sample } \\
\hline Ret & Market Return t & -0.83 & -0.12 & 0.17 & 0.11 & 0.37 & 3.14 \\
\hline $\mathrm{L}$ & Basic EPS t (level)/Price per share $t-1$ & -1.47 & 0.02 & 0.04 & 0.06 & 0.09 & 1.48 \\
\hline $\mathrm{C}$ & Change in Basic EPS $\mathrm{t}$ / Price per share $t-1$ & -1.49 & -0.02 & 0.01 & 0.01 & 0.03 & 1.50 \\
\hline
\end{tabular}

Regression model 1 incorporates Das et al. (2009) methodology with the original Easton and Harris (1991) model.

\section{Regression model 1 (to test hypotheses $\mathrm{H1}$ and H2):}

$$
\begin{aligned}
& \mathrm{R}_{\mathrm{jt}}=\alpha_{0 \mathrm{t}}+\beta_{1 \mathrm{t}}\left[\mathrm{L}_{\mathrm{jt}} / \mathrm{P}_{\mathrm{jt}-1}\right]+\beta_{2 \mathrm{t}}\left[\mathrm{C}_{\mathrm{jt}} / \mathrm{P}_{\mathrm{jt}-1}\right]+\beta_{3 \mathrm{t}}\left(\mathrm{Np}_{\mathrm{it}}\right)+\beta_{4 \mathrm{t}}\left(\mathrm{Pn}_{\mathrm{it}}\right)+\beta_{5 \mathrm{t}}\left(\mathrm{Np} * \mathrm{~L}_{\mathrm{jt}} / \mathrm{P}_{\mathrm{jt}-1}\right)+\beta_{6 \mathrm{t}}\left(\mathrm{Pn} * \mathrm{~L}_{\mathrm{jt}} / \mathrm{P}_{\mathrm{jt}-1}\right)+\beta_{7 t}\left(\mathrm{~Np} * \mathrm{C} / \mathrm{P}_{\mathrm{jt}-1}\right) \\
& +\beta_{8 \mathrm{t}}\left(\mathrm{Pn} * \mathrm{C} / \mathrm{P}_{\mathrm{jt}-1}\right)+\varepsilon_{\mathrm{jt}}
\end{aligned}
$$

Where:

$\boldsymbol{R}_{\boldsymbol{j} t}$ is the twelve month stock return.

$\boldsymbol{L}_{j t}$ is annualbasic EPS excluding discontinued operations and extraordinary items for the current year divided by the beginning of the year stock price $\left(\boldsymbol{P}_{j t-1}\right)$.

$\boldsymbol{C}_{\boldsymbol{j} t}$ is the change in annual basic EPS excluding discontinued operations and extraordinary items divided by the beginning of the year stock price $\left(\boldsymbol{P}_{j t-1}\right)$.

$\boldsymbol{N} \boldsymbol{p}_{\boldsymbol{j} t}$ is a dummy variable 1, for the firm's first seasonaldifferencing pattern of at least two of three lower interim quarters and a higher fourth quarter differencing pattern and 0 otherwise.

$\boldsymbol{P} \boldsymbol{n}_{\boldsymbol{j}}$ is a dummy variable 1, for the firm's first seasonaldifferencing pattern of at least two of three higher interim quarters and a lower fourth quarter differencing pattern and 0 otherwise. One additional constraint is placed upon the first Pn dummy, if the firm annualEPS was negative the observation is removed from the Pn subset based upon the assumption a firm generally would not be motivated to "round down" in a loss year.

$\left(\boldsymbol{N} \boldsymbol{p}_{j t} * \boldsymbol{L}_{j t} / \boldsymbol{P}_{\boldsymbol{j} t-1}\right)$ and $\left(\boldsymbol{P} \boldsymbol{n}_{\boldsymbol{j} t} * \boldsymbol{L}_{\boldsymbol{j} t} / \boldsymbol{P}_{\boldsymbol{j} t-1}\right)$ are the respective annual bas ic EPS earnings level interaction variables.

$\left(\boldsymbol{N} \boldsymbol{p}_{\boldsymbol{j} t} * \boldsymbol{C} / \boldsymbol{P}_{\boldsymbol{j t - 1}}\right)$ and $\left(\boldsymbol{P} \boldsymbol{n}_{\boldsymbol{j} t} * \boldsymbol{C} / \boldsymbol{P}_{\boldsymbol{j t - 1}}\right)$ are the respective change in annual EPS interaction variables. 
Regression model 2 tightens the assumption for an observation to qualify as a seasonal quarterly earnings patte rn. To qualify as a restricted $\mathrm{Np}$ ( $\mathrm{RNp}$ ) observation, the seasonal differencing for all three interim periods must be negative and the fourth quarter difference must be positive by .01 or more and to qualify as a restricted Pn (RPn) observation, the seasonal differencing for three interim periods must be positive and the fourth quarter differencing must be negative by -.01 or less. I also kept the Das et al. (2009) stipulation for Pn firms by removing all firms with an annual loss for their year-end.

\section{Regression model 2 (to test hypotheses $\mathrm{H3}$ and H4):}

$$
\begin{aligned}
& \mathrm{R}_{\mathrm{jt}}=\alpha_{0 \mathrm{t}}+\beta_{1 \mathrm{t}}\left[\mathrm{L}_{\mathrm{j} t} / \mathrm{P}_{\mathrm{jt}-1}\right]+\beta_{2 \mathrm{t}}\left[\mathrm{C}_{\mathrm{jt}} / \mathrm{P}_{\mathrm{jt}-1}\right]+\beta_{9 \mathrm{t}}\left(\mathrm{RNp} \mathrm{pjt}_{\mathrm{t}}\right)+\beta_{10 \mathrm{t}}\left(\mathrm{RPn}_{\mathrm{jt}}\right)+\beta_{11 \mathrm{t}}\left(\mathrm{RNp} * \mathrm{~L}_{\mathrm{jt}} / \mathrm{P}_{\mathrm{jt}-1}\right)+\beta_{12 \mathrm{t}}\left(\mathrm{RPn} * \mathrm{~L}_{\mathrm{j} t} / \mathrm{P}_{\mathrm{jt}-1}\right)+\beta_{13 \mathrm{t}} \\
& \left(\mathrm{RNp} * \mathrm{C} / \mathrm{P}_{\mathrm{jt}-1}\right)+\beta_{14 t}\left(\mathrm{RPn} * \mathrm{C} / \mathrm{P}_{\mathrm{jt}-1}\right)+\varepsilon_{\mathrm{jt}}
\end{aligned}
$$

Where:

$\boldsymbol{R}_{\boldsymbol{j} t}$ is the twelve month stock return.

$\boldsymbol{L}_{\boldsymbol{j} t}$ is annualbasic EPS excluding discontinued operations and extraordinary items for the current year divided by the beginning of the year stock price $\left(\boldsymbol{P}_{j t-1}\right)$.

$\boldsymbol{C}_{\boldsymbol{j} t}$ is the change in annualbasic EPS excluding discontinued operations and extraordinary items divided by the beginning of the year stock price $\left(\boldsymbol{P}_{j t-1}\right)$.

$\boldsymbol{R} \boldsymbol{N p _ { j t }}$ is a dummy variable 1, for the firm's first seasonaldifferencing pattern of three lower interim quarters and a higher fourth quarter differencing pattern and 0 otherwise.

$\boldsymbol{R} \boldsymbol{P} \boldsymbol{n}_{\boldsymbol{j} t}$ is a dummy variable 1, for the firm's first seasonaldifferencing pattern of three higher interim quarters and a lower fourth quarter differencing pattern and 0 otherwise. One additional constraint is placed upon the first RPn dummy, if the firm annual EPS was negative the observation is removed from the RPn subset based upon the assumption a firm generally would not be motivated to "round down" in a loss year.

$\left(\boldsymbol{R} \boldsymbol{N} \boldsymbol{p}_{j t} * \boldsymbol{L}_{j t} / \boldsymbol{P}_{\boldsymbol{j t - 1}}\right)$ and $\left(\boldsymbol{R} \boldsymbol{P} \boldsymbol{n}_{j t} * \boldsymbol{L}_{j t} / \boldsymbol{P}_{\boldsymbol{j t - 1}}\right)$ are the respective annual basic EPS earnings level interaction variables.

$\left(\boldsymbol{R N} \boldsymbol{p}_{j t} * \boldsymbol{C} / \boldsymbol{P}_{\boldsymbol{j t - 1}}\right)$ and $\left(\boldsymbol{R} \boldsymbol{P n _ { j t }} * \boldsymbol{C} / \boldsymbol{P}_{\boldsymbol{j t - 1}}\right)$ are the respective change in annual EPS interaction variables.

\section{RESULTS}

The focus of this paper is on the "first event" or first time a firm qualifies as an Np or Pn firm and comparing how the earnings coefficients differ between the pre-event versus post-event to see if the market can identify the seasonal quarterly differencing pattern. The importance being the as sociation of the seasonal quarterly differencing pattern to firms identified as possible earnings management firms (Das et al. 2009). If the market sees the pattern then this is evidence against the conventional wisdom that managing earnings fools the market.

\section{Regression 1 Results}

Table 3- Regression 1 presents the pooled cross-section results for the total sample of 30,904 observations from 2,670 firms using Das et al. (2009) identification criteria. The earnings level (L) and change in earnings levels (C), representing the "pre-event" results are positive and statistically significant" similar to Easton and Harris (1991). For the 1,233 "first-time" $\mathrm{Np}$ events, the dummy variable is negative $(-0.10)$ and statistically significant. The earnings level interaction coefficient $(\mathrm{NpL})$ is negative $(-0.17)$ and significant at the $10 \%$ level while the change in earnings level interaction coefficient is negative but not significant. The evidence suggests the market sees the Np pattern but assesses the new information as transitory at best. For the 1,291 "first-time" Pn events, the dummy

${ }^{7}$ Statistically significant means at the $1 \%$ level unless noted otherwise. 
variable is also negative (-0.08) and statistically significant. The earnings level interaction coefficient (PnL) is positive (1.18) and statistically significant while the change in earnings level interaction coefficient is negative but not significant. It appears the market sees the Pn pattern and finds the "post-event" earnings more informative, but transitory.

While not presented in this paper, I ran the Regression 1 model on per year basis. The two Easton and Harris (1991) variables- earnings levels and changes in earnings levels were statistically significant at the 5\% level or better over $90 \%$ of the time. The yearly $\mathrm{Np}$ and Pn dummy variables were statistically significant at the $5 \%$ level or bett er $75 \%$ and $45 \%$ respectively. The two interactions variables for either dummy variable tended not to be significant on an annual basis.

\section{Regression 2 Results:}

In Table 3- Regression 2 represents a tighter constraint to qualify as a restricted "first-time" firm. To qualify as a restricted $\mathrm{RNp}$, the seasonal differencing for all three interim periods must be negative and the fourth quarter difference must be positive by .01 or more and on the other hand to qualify as a restricted RPn the seasonal differencing for all three interim periods must be positive and the fourth quarter difference must be negative by -.01 or less. I kept the additional Das et al. (2009) stipulation for RPn firms by removing all firms with an annual loss for the traditional year-end. There are 9,693 observations for 517 firms in this pooled cross-section test for the same period of time (1971 -2006).

Regression 2 results are similar to regression 1's. The earnings level (L) and change in earnings levels (C), representing the "pre-event" results are positive and statistically significant consistent with Easton and Harris (1991). The market sees the "first event" for both restricted patterns; the dummy variables are negative and statistically significant. For the restricted $\mathrm{Np}$ events, the earnings level interaction coefficient (RNpL) is negative but not significant. The changes in earnings level coefficient (RNpC) is negative (-0.72) and significant which suggests the market responded negatively to the new information and believes the information to be more permanent in nature. For the restricted Pn events, the earnings level interaction coefficient (RPnL) is positive (1.28) and statistically significant while the change in earnings level coefficient while positive was not sig nificant.

Table 3. Regression Results

\begin{tabular}{|c|c|c|c|}
\hline \multicolumn{4}{|c|}{ Dependent Variable $=$ Ret } \\
\hline Variable & Definition & Regression 1 & Regression 2 \\
\hline \# of Observations & & 30,904 & 9,693 \\
\hline \# of Firms & & 2,670 & 517 \\
\hline Intercept & & $0.14 * * *$ & $0.12 * * *$ \\
\hline $\mathrm{L}$ & Basic EPSt (Level)/Price per share t-1 & $0.54 * * *$ & $0.62 * * *$ \\
\hline $\mathrm{C}$ & Change in Basic EPSt/ Price per share $t-1$ & $0.46^{* * *}$ & $0.46^{* * *}$ \\
\hline $\mathrm{Np}$ & Dummy Variable for 1st NP & $-0.10 * * *$ & \\
\hline $\mathrm{Pn}$ & Dummy Variable for 1st PN & $-0.08 * * *$ & \\
\hline $\mathrm{NpL}$ & NP EPS Level Interaction & $-0.17 *$ & \\
\hline PnL & PN EPS Level Interaction & $1.18 * * *$ & \\
\hline $\mathrm{NpC}$ & NP EPS Change Interaction & -0.19 & \\
\hline $\mathrm{PnC}$ & PN EPS Change Interaction & -0.15 & \\
\hline $\mathrm{RNp}$ & Restricted Dummy Variable for 1st NP & & $-0.10 * * *$ \\
\hline $\mathrm{RPn}$ & Restricted Dummy Variable for 1st PN & & $-0.13 * * *$ \\
\hline RNpL & Restricted NP EPS Level Interaction & & -0.03 \\
\hline RPnL & Restricted PNEPS Level Interaction & & $1.28 * * *$ \\
\hline $\mathrm{RNpC}$ & Restricted NP EPS Change Interaction & & $-0.72 * * *$ \\
\hline $\mathrm{RPnC}$ & Restricted PN EPS Change Interaction & & 0.16 \\
\hline R2 & & 0.075 & 0.108 \\
\hline Adj R2 & & 0.073 & 0.107 \\
\hline
\end{tabular}

Significance levels: $* 10 \%, * * 5 \%, * * * 1 \%$. 


\section{Robustness Checks}

I successfully replicated Easton and Harris (1991) prior to amending their model both for the pooled cross-section and the time-series results from 1987 through 2006 (yearly results are not presented in the paper). I removed all firm/year observations with less than four consecutive annual observations. I comp uted the variance inflation factor (VIF) which measures the degree of multicollinearity among variables. Easton and Harris (1991) used the statistic of 10 as the critical value for severe collinearity. For my sample, the VIF statistic ranged from 1.1 to 8 for the first event regressions. I tested my total sample regressions using the two-way cluster-robust standard errors (CL-2) (Gow, Ormazabal \& Taylor 2010). Two-way clustering is a test for both cross-sectional and time-series dependence within the panel data. The authors supplied the SAS code from their website to permit the testing. The coefficient estimates provided were similar to the original regressions in terms of direction, magnitude, and statistical significance.

\section{CONCLUSION AND FUTURE RESEARCH}

Is the market fooled by the seasonal quarterly differencing pattern or is the pattern actually more informative? Does the pattern provide supporting evidence of earnings management where firms try to fool the market or does the pattern provide more information and is perhaps used as a signal of good news by firms?

The market seems to punish (reward) the $\mathrm{Np}(\mathrm{Pn})$ firms for the identified patterns. My results are in line with Defond and Park (2001) and Das et al. (2009) who expected higher earnings response coefficients (ERC) when accruals suppress earnings surprises and lower ERCs when accruals are used to magnify earnings surprises. The significance of the coefficients on the earnings levels variables (1.18 for PnL variable in regression \#1 and 1.28 for $\mathrm{RPnL}$ in regression \#2) suggest the market sees pattern but perceives the information as transitory. In regression \#2 the ERC on the RNpC variable was (-0.72) and statistically significant suggesting the degree of "new" information was perceived as negative by the market.

My results suggest the market sees through the seasonal quarterly earnings patterns, especially the Np pattern; therefore the patterns don't fool the market and generally speaking the earnings variables are more informative. Although my findings are consistent with Das et al. (2009)'s argument that seasonal quarterly differencing patterns may indicate potential earnings management behavior, future research is needed to test whether management's intent is to deceive or to signal additional information.

\section{AUTHOR INFORMATION}

John M. Carlson, Ph.D., CPA, is an assistant professor of economics and management at Albion College. Dr. Carlson received his Ph.D. in accounting from the University of Cincinnati. E-mail: jmcarlson@albion.edu

\section{REFERENCES}

Ali, A. \& Zarowin, P. (1992). The role of earnings levels in annual earnings-returns studies. Journal of Accounting Research 30, 286-296.

Badertscher, Brad A. (2011). Overvaluation and the choice of alternative earnings management mechanisms. The Accounting Review, 86 (5), 1491-1518.

Ball R. \& Bartov, E. (1996). How naïve is the stock market's use of earnings information. Journal of Accounting and Economics, 21, 319-337.

Ball, R. \& Brown, P. (1968). An empirical evaluation of accounting numbers. Journal of Accounting Research (Autumn), 159178.

Barth, M., Elliott, J. \& Finn, M.(1999). Market rewards associated with patterns of increasing earnings. Journal of Accounting Research, 37 (2). 387-413.

Barton, J. \& Simko, P. (2002). The balance sheet as an earnings management constraint. The Accounting Review, 77 supplement, 1-27.

Basu, Sudipta. (1997). The conservatism principle and the asy mmetric timeliness of earnings. Journal of Accounting and Economics, 24, 3-37. 
Beaver, W., Lambert, R. \& Morse, D. (1980). Information content of security prices. Journal of Accounting and Economics 2, 328.

Beidleman, Carl. (1973). Income smoothing: the role of management. The Accounting Review, 48 (4), 653-667.

Burgstahler, D.\& Dichev, I.D., (1997). Earnings management to avoid earnings decreases and losses. Journal of Accounting and Economics 24, 99-126.

Carlson, John M.(2012). Does the market see through seasonal quarterly earnings patterns? (unpublished doctoral dissertation) University of Cincinnati, Cincinnati, Ohio.

Das, S., Shroff, P. \& Zhang, H. (2009). Quarterly earnings patterns and earnings management. Contemporary Accounting Research 24( 3), 797-831.

Defond, M.\& Park, C. (2001). The reversal of abnormal accruals and the market valuation of earnings surprises. The Accounting Review, 78(3), 375-404.

Degeorge, F., Patel, J. \& Zeckhauser, R. (1999). Earnings management to exceed thresholds. Journal of Business 72(1), 1-33.

Easton, P. \& Harris, T. (1991). Earnings as an explanatory variable for returns. Journal of Accounting Research 29, 19-36.

Easton, P., Harris, T. \& Ohlson, J. (1992). Aggregate accounting earnings can explain most of security returns. Journal of Accounting and Economics 15, 119-142.

Fama, E. (1991). Efficient capital markets II. The Journal of Finance 46, 1-38.

Graham, J., Harvey, C.R. \& Rajgopal, J. (2005). The economic implications of corporate financial reporting. Journal of Accounting and Economics 40, 3-73.

Gow I.D., Ormazabal, G., Taylor, D.T. (2010). Correcting for cross-sectional and time-series dependence in accounting research. The Accounting Review, 85( 2), 483-512.

Healy, P. M.\& Wahlen, J.M. (1999). A review of the earnings management literature and its implications for standard settings. Accounting Horizons 13(4), 365-383.

Hirshleifer,D., Hou, K., Teoh, S.\& Zhang, Y.(2004). Do investors overvalue firms with bloated balance sheets? Journal of Accounting and Economics 38, 297-331.

Kieso, D., Wey gandt, J. \& Warfield, T. (2012) Intermediate Accounting, 14th Edition. John Wiley \& Sons, Inc.

Ohlson, J. \& Shroff, P. (1992). Changes versus levels in earnings as explanatory variables for returns: some theoretical considerations. Journal of Accounting Research 30, 210-226.

Palepu, K.G., Healy, Paul M., Bernard, Victor L. \& Peek, Erik. (2007). Business Analysis and Valuation: IFRS Edition. Thomp son Learning.

Penman, Stephen H. (2007). Financial Statement Analysis and Security Valuation: Third Edition. McGraw-Hill Irwin.

Ronen, J. \& Sadan, S. (1981). Smoothing Income Numbers: Objectives, Means, and Implications. Addison-Wesley Publishing Company .

Schipper, K. (1989). Commentary on earnings management. Accounting Horizons 3, 91-102.

Skinner, D. \& Sloan, R. (2002). Earnings surprises, growth expectations, and stock returns or don't let an earnings torpedo sink your portfolio. Review of Accounting Studies 7, 289-312.

Trueman, B. \& Titman, S. (1988). An explanation for accounting income smoothing. Journal of Accounting Research, 127-139.

Warfield, T.\& Wild, J. (1992). Accounting recognition and the relevance of earnings as an explanatory variable for returns. The Accounting Review 67(4), 821-042.

Wiedman, Christine I. (2009) Discussion of "Quarterly Earnings Patterns and Earnings Management". Contemporary Accounting Research 26 (3). 833-841. 


\section{NOTES}

